\title{
Review of the book entitled Research Methods in Tourism, Hospitality \& Events Management by Paul Brunt, Susan Horner \& Natalie Semley; 344 pages, Publisher: Sage, Year: 2017
}

\author{
Jasna Potočnik Topler, Faculty of Tourism, Brežice, Slovenia
}

When tourism and hospitality students come across the word "research", they very often associate it with a challenge. In fact, when it comes to students actually practicing research work in their seminar papers, bachelor's or master's theses, it commonly turns out that research actually represents a challenge to a great many of them. This is not the case only at universities in the region, but also elsewhere, for example at the University of Plymouth in Great Britain, where Professor Paul Brunt, Dr Susan Horner and Dr Natalie Semley from the School of Tourism and Hospitality decided to tackle the challenge by joining their collective experience of teaching research methods on undergraduate, postgraduate and doctoral programmes and write the book entitled Research Methods in Tourism, Hospitality \& Events Management. The book on 344 pages provides some very useful guidance throughout the whole process of research from initial ideas to writing the paper, and presenting the results. The authors also use real examples and illustrations taken from their own and their students' work to guide the reader through the research process comprehensibly. The book has nine chapters entitled 1 What is research?, 2 (Market) research methods, 3
Planning a project, 4 Selecting a sample, 5 Quantitative data collection methods, 6 Qualitative data collection methods, 7 Analysing the data: a quantitative approach, 8 Analysing the data: a qualitative approach, and 9 Writing up, presenting and publishing the results. The chapters begin by outlining preparation of a research proposal, give practical suggestions, touch ethical considerations, and provide suggestions for selected further reading at the end of each chapter. Unlike other similar books available that cover research methods and tourism methodology, this textbook covers also the digital environment as a space for performing research. What is more, the book provides the reader with case studies of actual research undertaken, and guides you through data analysis in SPSS and NVivo. The book is complemented by hints, tips, exercises, examples from tourism destinations from Spain, Switzerland, Italy and India, and a selection of PowerPoint slides for lectures. Recommended for undergraduate and postgraduate students of Tourism, Hospitality, Marketing, or Events Management! 
Potočnik Topler, J. - Research Methods in Tourism, Hospitality \& Events Management - Review 2018. Fakultet za sport i turizam, Novi Sad, Tims.Acta 12, 133-134

Datum prijave: 06.06.2018.

Datum prihvatanja: 08.06. 2018.

\section{Kontakt}

Jasna Potočnik Topler, University of Maribor,

Faculty of Tourism, Brežice

Cesta prvih borcev 36, Brežice, Slovenia

E-mail: jasna.potocnik1@um.si 